\title{
PERAWATAN DIRI PASIEN SKIZOFRENIA DENGAN HALUSINASI
}

\author{
Novi Herawati*, Yudistira Afconneri \\ Program DIII Keperawatan Solok, Poltekkes Kemenkes Padang, Jl. Raya Siteba, Surau Gadang, Kec. Nanggalo, \\ Kota Padang, Sumatera Barat, Indonesia 25146 \\ *ophie_cut@yahoo.com
}

\begin{abstract}
ABSTRAK
Pasien skizofrenia dengan halusinasi dapat mengalami gangguan perawatan diri karena adanya perubahan proses pikir, mengakibatkan terjadinya gangguan membran mukosa mulut, gatal-gatal dan infeksi di bagian tubuh lainnya. Pasien skizofrenia Kota Solok tahun 2018 berjumlah 156 orang dimana 51 orang diantaranya halusinasi, terbanyak terdapat di Puskesmas Tanjung Paku yaitu 32 orang $(42,67 \%)$. Tujuan penelitian untuk mengetahui gambaran perawatan diri pasien skizofrenia dengan halusinasi di wilayah kerja Puskesmas Tanjung Paku Kota Solok tahun 2019. Penelitian bersifat deskriptif, pengumpulan data secara observasi pada September-Oktober 2019 di wilayah kerja Puskesmas Tanjung Paku Kota Solok tahun 2019. Populasi penelitian adalah seluruh pasien halusinasi yang pernah dirawat di RSJ dan berobat di Puskesmas Tanjung Paku, sejumlah 32 orang. Teknik sampel menggunakan total sampling. Data diolah secara manual dan dianalisa secara univariat untuk ditampilkan berupa tabel distribusi frekuensi. Hasil penelitian diperoleh lebih dari sebahagian $(62,5 \%)$ responden tampak bersih dalam kebersihan dirinya, sebahagian besar (75\%) responden tampak mampu dalam berhias diri. Hampir keseluruhan $(96,9 \%)$ responden tampak mampu dalam makan, dan hampir keseluruhan $(96,9 \%)$ responden tampak bersih setelah BAB/BAK.
\end{abstract}

Kata kunci: halusinasi, perawatan diri, skizofrenia

\section{SELF-HEALTH CARE OF SCIZOPHFRENIA PATIENTS WITH HALUSINATION}

\begin{abstract}
Schizophrenic patients with hallucinations can experience self-care disorders due to changes in thought processes, resulting in disruption of the oral mucous membrane, itching and infection in other parts of the body. Schizophrenic patients in Solok City in 2018 totaled 156 people, of which 51 were hallucinations, most were in the Tanjung Paku Health Center, 32 people (42.67\%). The purpose of this study was to determine the description of self-care schizophrenia patients with hallucinations in the working area of Tanjung Paku Health Center in Solok City in 2019. The study was descriptive, observational data collection in September-October 2019 in the working area of Tanjung Paku Health Center in Solok City in 2019. The study population was all hallucination patients who had been treated at the mental hospital and treated at the Tanjung Paku Health Center, a total of 32 people. The sampling technique uses total sampling. Data is processed manually and analyzed univariately to be displayed in the form of a frequency distribution table. The results obtained by more than half $(62.5 \%)$ of respondents looked clean in their personal hygiene, most (75\%) of respondents seemed able to decorate themselves. Almost all (96.9\%) respondents seemed able to eat, and almost all (96.9\%) respondents looked clean after defecation.
\end{abstract}

Keywords: hallucinations, self-care, schizophrenia

\section{PENDAHULUAN}

Sehat menurut World Health Organization (WHO), merupakan suatu keadaan sempurna baik fisik, mental dan sosial serta bukan saja keadaan terhindar dari sakit maupun kecacatan. Sehat adalah simbol perkembangan kepribadian dan proses kehidupan manusia yang kreatif dan konstruktif (Riyadi \&Purwanto, 2009). Seseorang dikatakan sehat jika mampu berkarya, mampu bersosialisasi, dan menikmati waktu senggang. WHO menyatakan, jika $10 \%$ dari populasi mengalami masalah kesehatan jiwa maka hal ini harus mendapatkan perhatian karena hal ini termasuk rawan kesehatan jiwa (Yosep, 2009).

Kesehatan jiwa menurut WHO adalah beberapa karakteristik positif yang menggambarkan keselarasan dan keseimbangan jiwa yang tercermin dalam kedewasaan kepribadiaan seseorang. Menurut UU No. 3 tahun 1996, kesehatan jiwa adalah 
kondisi yang memungkinkan perkembangan fisik, intelektual, emosional secara optimal dari seseorang, dan perkembangan ini berjalan selaras dengan orang lain (Kusumawati \& Hartono, 2010).

Berbagai pengertian diatas dapat disimpulkan bahwa kesehatan jiwa adalah suatu kondisi perasaan sejahtera secara subyektif, suatu penilaian diri tentang perasaan mencakup aspek konsep diri, kebugaran, dan kemampuan dalam pengendalian diri. Indikator mengenai keadaan sehat mental, psikologis, jiwa yang minimal adalah individu tidak merasa tertekan atau depresi (Riyadi \& Purwanto, 2009).

Gangguan jiwa merupakan suatu sindrom perubahan psikologis atau perilaku yang secara klinik terjadi pada seseorang dan dapat dikaitkan dengan adanya distres (misalnya gejala nyeri) atau disabilitas (yaitu kerusakan pada satu atau lebih area fungsi yang penting) atau disertai peningkatan resiko kematian yang menyakitkan. Fungsi kejiwaan meliputi proses berpikir, emosi, kemauan, perilaku psikomotorik, dan bicara. Disimpulkan dari definisi diatas maka diketahui bahwa gangguan jiwa adalah suatu sindrom atau pola psikologis yang berkaitan dengan adanya gangguan pada fungsi kejiwaan meliputi proses berpikir, emosi, kemauan, psikomotorik dan bicara (Videbeck, 2008).

Gangguan jiwa merupakan manifestasi dari bentuk penyimpangan perilaku akibat adanya distorsi emosi sehingga ditemukan ketidakwajaran dalam bertingkah laku. Hal ini terjadi karena menurunnya semua fungsi kejiwaan(Nasir \& Muhith, 2011). Diperkiraan penduduk Indonesia yang menderita gangguan jiwa sebesar 2-3\% jiwa. Zaman dahulu penanganan pasien gangguan jiwa adalah dengan dipasung, dirantai, atau diikat, lalu ditempatkan tersendiri di rumah atau hutan jika gangguan jiwa berat. Bila tidak berbahaya, dibiarkan berkeliaran di desa, sambil mencari makanan dan menjadi tontonan masyarakat (Kusumawati \& Hartono, 2010: 16). Salah satu upaya yang dilakukan pemerintah melalui Kementerian Kesehatan adalah menjadikan Indonesia bebas pasung oleh karena tindakan pemasungan dan perlakukan salah merupakan tindakan yang melanggar hak asasi manusia (Balitbangkes Kemenkes RI, 2013).

Gangguan jiwa berat adalah gangguan jiwa yang ditandai oleh terganggunya kemampuan menilai realitas atau tilikan (insight) yang buruk. Gejala yang menyertai gangguan ini antara lain berupa halusinasi, ilusi, waham, gangguan proses pikir, kemampuan berpikir, serta tingkah laku aneh, misalnya agresivitas atau katatonik. Gangguan jiwa berat dikenal dengan sebutan psikosis dan salah satu contoh psikosis adalah skizofrenia(Balitbangkes Kemenkes RI, 2013).

Konferensi tahunan The American Psychiatric Association/APA di Miami, Florida, Amerika Serikat bahwa di Amerika Serikat angka pasien skizofrenia cukup tinggi (lifetime prevalence rates) mencapai $1 / 100$ penduduk. Berdasarkan data di Amerika Serikat, setiap tahun terdapat 300.000 pasien skizofrenia mengalami episode akut, $20 \%-50 \%$ pasien skizofrenia melakukan percobaan bunuh diri dan 10\% diantaranya berhasil (mati bunuh diri). Angka kematian pasien skizofrenia 8 kali lebih tinggi dari angka kematian penduduk pada umumnya (Yosep, 2009).

Berdasarkan Balitbangkes Kemenkes RI (2018) prevalensi rumah tangga dengan ART gangguan jiwa skizofrenia/psikosis megalami peningkatan dari tahun 2013 - 2018. Pada tahun 2013 prevalensi gangguan jiwa berat pada penduduk Indonesia 1,7 per mil. Dengan angka gangguan jiwa tertinggi ada di DI Yogyakarta sebesar 2,7 per mil. Sedangkan Prevalensi di Sumatera Barat 1,9 per mil. Sementara itu, pada tahun 2018 prevalensi gangguan jiwa berat pada penduduk Indonesia mengalami kenaikan sebesar 7,0 per mil. Gangguan jiwa berat tertinggi berada di Bali 11,0 per mil. Prevalensi di Sumatera barat sebesar 9,0 per mil. Proporsi RT yang pernah memasung ART gangguan jiwa berat sebesar $14,0 \%$ dan terbanyak pada penduduk yang tinggal di perdesaan $(17,7 \%)$, serta pemasungan ART gangguan jiwa berat 3 bulan terakhir $31,5 \%$. Maka dapat disimpulkan bahwa prevalensi angka kejadian gangguan jiwa di Sumatera Barat 9,0\% per mil melebihi dari prevalensi nasional 7,0 per mil (Balitbangkes Kemenkes RI, 2018).

Jumlah pasien yang mengalami gangguan jiwa di Kota Solok pada tahun 2017 yaitu sebanyak 133 orang, yang tersebar di 4 puskesmas. Dimana puskesmas Tanjung Paku 61 orang (45,8\%), Puskesmas Nan Balimo 27 orang (20,3\%), Puskesmas Tanah Garam 25 orang $(18,7 \%)$, dan Puskesmas KTK 20 orang $(15,2 \%)$. Berdasarkan data tersebut Puskesmas 
Tanjung Paku merupakan Puskesmas tertinggi dengan jumlah pasien gangguan jiwa terbanyak yaitu 61 orang $(45,8 \%)$. Dimana 51 orang diantaranya menderita skizofrenia dan salah satunya meninggal dunia karena komplikasi Diabetes Melitus, sehingga sekarang pasien berjumlah 50 orang (Dinas Kesehatan Kota Solok, 2017).

Jumlah pasien skizofrenia terbanyak diantara 4 puskesmas tersebut yaitu Puskesmas Tanah Garam sebanyak 57 orang (36,54\%) dari 156 orang jumlah pasien skizofrenia. Sementara itu, pasien halusinasi yang terbanyak terdapat di Puskesmas Tanjung Paku sebanyak 32 orang $(42,67 \%)$ penderita halusinasi (Laporan Dinas Kesehatan Kota Solok tahun 2018).

Skizofrenia merupakan salah satu bentuk gangguan jiwa yang terdapat di seluruh dunia. Skizofrenia adalah salah satu gangguan jiwa berat yang dapat mempengaruhi pikiran, perasaan dan perilaku individu. Menurut Sadock, dkk (2014) skizofrenia adalah bagian dari gangguan psikosis yang terutama ditandai dengan kehilangan pemahaman terhadap realitas dan hilangnya daya tilik diri (Yudhantara \& Istiqomah, 2018: 1). Skizofrenia adalah sindrom etiologi yang tidak diketahui dan ditandai dengan distorsi gangguan kognisi, emosi, persepsi, pemikiran, dan perilaku (Sutejo, 2017).

Satu ciri khas skizofrenia adalah halusinasi (persepsi sensoris yang tidak benar dan tidak berdasarkan realitas). Halusinasi dapat menyangkut lima indera dan sensasi tubuh yang lain (Baradero, 2010: 139). Halusinasi sering diidentikkan dengan skizofrenia. Dari seluruh skizofrenia, $70 \%$ diantaranya mengalami halusinasi (Purba, 2010). Halusinasi tidak sama dengan ilusi. Ilusi adalah persepsi yang keliru tentang sesuatu yang real di lingkungan (Baradero, 2010: 139). Sementara itu, halusinasi adalah hilangnya kemampuan manusia dalam membedakan rangsangan internal (pikiran) dan rangsangan eksternal (dunia luar). Klien memberi persepsi atau pendapat tentang lingkungan tanpa objek atau rangsangan yang nyata (Kusumawati \& Hartono, 2010).

Menurut Cancron \& Lehman (2000), bahwa halusinasi terbagi dari beberapa macam yaitu halusinasi auditori (pendengaran), halusinasi visual (penglihatan), halusinasi olfaktori (penciuman), halusinasi taktil (sentuhan), halusinasi gustatori (pengecapan), dan halusinasi kinestetik (Baradero, 2010).

Pasien gangguan jiwa kronis sering mengalami ketidakpedulian merawat diri yang merupakan gejala negatif, hal ini menyebabkan pasien dikucilkan dalam keluarga maupun di masyarakat (Keliat, Budi Anna, 2011). Berdasarkan hasil penelitian yang dilakukan oleh Holmberg \& Kane (1999) yang bertujuan untuk melihat perawatan diri dan kesehatan pasien menunjukkan bahwa pasien psikiatri kurang melakukan perawatan diri atau kegiatan aktivitas kesehatan (Andayani, 2012).

Menurut Orem (2001), defisit perawatan diri adalah hubungan antara tuntutan perawatan diri terapeutik individual dan kekuatan agen perawatan dirinya dimana kemampuan perawatan diri yang telah dikembangkan di dalam agen perawatan diri tidak bisa dioperasikan atau tidak memadai untuk mengetahui dan memenuhi beberapa atau semua komponen permintaan perawatan diri terapeutik yang ada atau yang diproyeksikan (Hamid \& Ibrahim, 2017).

Kurang perawatan diri pada pasien dengan gangguan jiwa terutama pada pasien halusinasi terjadi akibat adanya perubahan proses pikir sehingga kemampuan untuk melakukan aktivitas perawatan diri menurun. Kurang perawatan diri tampak dari ketidakmampuan merawat kebersihan diri, ketidakmampuan makan secara mandiri, ketidakmampuan berhias diri secara mandiri, dan ketidakmampuan toileting (BAB/BAK) secara mandiri (Purba, 2010).

Akibat yang dapat ditimbulkan jika personal hygiene tidak terpenuhi diantaranya adalah gangguan membrane mukosa mulut, gatalgatal, dan infeksi di beberapa bagian tubuh, serta gangguan integritas kulit dan gangguan fisik pada kuku. Selain dapat menimbulkan dampak fisik, gangguan personal hygiene dapat pula menimbulkan dampak psikososial. Diantaranya adalah gangguan kebutuhan rasa nyaman dan kebutuhan harga diri (Kasiati \& Rosmalawati, 2016).

Hasil studi pendahuluan yang peneliti lakukan di wilayah kerja Puskesmas Tanjung Paku Kota Solok pada Februari 2019 dengan mewawancarai salah seorang petugas program jiwa di Puskesmas Tanjung Paku Kota Solok disampaikan bahwa pasien yang berobat ke 
Puskesmas Tanjung Paku rata-rata pasien yang sudah pernah dirawat di rumah sakit jiwa dan sudah terpapar dengan tindakan keperawatan dalam perawatan diri. Sementara itu, dari hasil wawancara terhadap salah satu kader jiwa di Wilayah Kerja Puskesmas Tanjung Paku Kota Solok bahwa belum ada program dari kader jiwa dalam memberikan kunjungan rumah pada pasien defisit perawatan diri. Jenis penelitian ini adalah deskriptif. Tujuan penelitian adalah untuk mengetahui gambaran perawatan diri pasien skizofrenia dengan halusinasi di wilayah kerja Puskesmas Tanjung Paku Kota Solok Tahun 2019.

\section{METODE}

Penelitian ini bersifat deskriptif. Variabel penelitian yaitu perawatan diri pasien skizofrenia dengan halusinasi, meliputi: kebersihan diri, makan, berhias dan toileting. Populasi dalam penelitian ini adalah pasien skizofrenia dengan halusinasi di Wilayah Kerja Puskesmas Tanjung Paku Kota Solok tahun 2019, berjumlah 32 orang. Sampel pada penelitian ini adalah seluruh populasi.

Teknik pengambilan sampel dengan total sampling. Sehingga didapatkan sampel 32 orang. Pengumpulan data dilakukan dengan cara observasi dengan menggunakan instrument ceklist, yang berisi item aspek tanda dan gejala defisit perawatan diri yang dapat diobservasi menurut Purba (2010). Aspek tersebut antara lain: (1)Gangguan kebersihan diri, ditandai dengan rambut kotor, gigi kotor, kulit berdaki dan bau, kuku panjang dan kotor. (2)Ketidakmampuan berhias/ berdandan, ditandai dengan rambut acakacakan, pakaian kotor dan tidak rapi, pakaian tidak sesuai, pada pasien laki-laki tidak bercukur, pada pasien wanita tidak berdandan. (3)Ketidakmampuan makan secara mandiri, ditandai dengan ketidakmampuan mengambil makan sendiri, makan berceceran, dan makan tidak pada tempatnya. (4)Ketidakmampuan defekasi/ berkemih secara mandiri, ditandai dengan defekasi/ berkemih tidak pada tempatnya, tidak membersihkan diri dengan baik setelah defekasi/ berkemih.Analisa dilakukan secara univariat yang disajikan dalam tabel distribusi frekuensi.

\section{HASIL}

Hasil penelitian mengenai Gambaran Perawatan Diri Pasien Skizofrenia Dengan Halusinasi di Wilayah Kerja Puskesmas Tanjung Paku kota Solok Tahun 2019. Penelitian ini dilakukan pada bulan SeptemberOktober 2019, dengan jumlah responden sebanyak 32 orang. Hasil penelitian berupa hasil analisis univariat. Karakteristik responden mencakup umur, jenis kelamin, pendidikan, pekerjaan, dan status perkawinan dapat dilihat pada tabel 1 .

Tabel 1

Karakteristik responden berdasarkan umur, jenis kelamin, tingkat pendidikan, status pernikahan, rutinitas berobat $(n=32)$

\begin{tabular}{|c|c|c|}
\hline Karakteristik responden & $\mathrm{f}$ & $\%$ \\
\hline \multicolumn{3}{|l|}{ Umur } \\
\hline $20-39$ & 4 & 12.5 \\
\hline $40-59$ & 18 & 56.3 \\
\hline$>60$ & 10 & 31.2 \\
\hline \multicolumn{3}{|l|}{ Jenis Kelamin } \\
\hline Laki-Laki & 24 & 75 \\
\hline Perempuan & 8 & 25 \\
\hline \multicolumn{3}{|l|}{ Pendidikan } \\
\hline Tamat SD & 13 & 40.6 \\
\hline Tamat SMP & 6 & 18.8 \\
\hline Tamat SMA & 10 & 31.2 \\
\hline Tamat PT & 3 & 9.4 \\
\hline \multicolumn{3}{|l|}{ Status Pernikahan } \\
\hline Belum Menikah & 21 & 65.6 \\
\hline Nikah & 5 & 15.6 \\
\hline Cerai & 6 & 18.8 \\
\hline \multicolumn{3}{|l|}{ Rutinitas Berobat } \\
\hline Rutin & 25 & 78.1 \\
\hline Tidak Rutin & 7 & 21.9 \\
\hline
\end{tabular}


Tabel 1 menunjukkan bahwa karakteristik responden lebih dari sebahagian $(56,3 \%)$ berada pada kelompok umur 40-59 tahun atau termasuk golongan usia dewasa tengah, sebagian besar berjenis kelamin laki-laki (75 $\%)$, hampir sebahagian $(40,6 \%)$ tamat SD, lebih dari sebahagian $(65,6 \%)$ belum nikah serta sebagian besar rutin berobat ke pelayanan kesehatan $(78.1 \%)$.
Analisa univariat bertujuan mengetahui gambaran perawatan diri pasien skizofrenia dengan halusinasi di wilayah kerja Puskesmas Tanjung Paku Kota Solok tahun 2019. Meliputi perawatan diri dalam kebersihan diri, dalam berhias diri, dalam makan dan dalam BAB/BAK. Maka dapat kita lihat pada uraian berikut:

Tabel 2

Distribusi ( $\mathrm{n}=32)$

\begin{tabular}{ccc}
\hline Perawatan diri dalam Kebersihan diri & f & $\%$ \\
\hline Bersih & 20 & 62.5 \\
\hline Kurang Bersih & 12 & 37.5 \\
\hline
\end{tabular}

Tabel 2 dapat terlihat bahwa lebih dari sebahagian $(62,5 \%)$ responden tampak bersih

dalam kebersihan dirinya.

Tabel 3

Distribusi frekuensi responden berdasarkan perawatan diri dalam berhias diri $(\mathrm{n}=32)$

\begin{tabular}{ccc}
\hline Perawatan diri dalam berhias diri & f & $\%$ \\
\hline Mampu & 24 & 75 \\
Kurang Mampu & 8 & 25 \\
\hline
\end{tabular}

Tabel 3dapat terlihat bahwa sebahagian besar

$(75 \%)$ responden mampu dalam berhias diri.

Tabel 4

Distribusi Frekuensi Responden Berdasarkan Perawatan Diri Dalam Makan ( $\mathrm{n}=32)$

\begin{tabular}{ccc}
\hline Perawatan diri dalam Makan & f & $\%$ \\
\hline Mampu & 31 & 96.9 \\
Kurang Mampu & 1 & 3.1 \\
\hline
\end{tabular}

Tabel 4 menunjukkan hampir keseluruhan

$(96,9 \%)$ responden mampu makan.

Tabel 5

Distribusi frekuensi responden berdasarkan perawatan diri dalam BAB/BAK $(n=32)$

\begin{tabular}{ccc}
\hline Perawatan diri dalam BAB/BAK & $\mathrm{f}$ & $\%$ \\
\hline Bersih & 31 & 96.9 \\
Kurang Bersih & 1 & 3.1 \\
\hline
\end{tabular}

Tabel 4 dapat terlihat bahwa hampir keseluruhan $(96,9 \%)$ responden tampak bersih setelah BAB/BAK.

\section{PEMBAHASAN}

Hasil penelitian ini tidak sejalan dengan hasil penelitian oleh Andayani (2012) dimana didapatkan rerata usia pasien Skizofrenia 34,39 tahun dan penelitian Üçok, Karadayi, Emiroğlu, dan Sartorius (2013) yang mendapatkan usia rata-rata pasien Skizofrenia di sebuah rumah sakit jiwa di Turki yaitu 31,49 tahun.

Usia berhubungan dengan pengalaman individu terhadap stressor kehidupan, jenis sumber dukungan dan kemampuan koping serta dapat menggambarkan kemampuan pasien untuk menggunakan fasilitas kesehatan
(Stuart, 2013). Hal ini seiring dengan penelitian Andayani (2012) dan penelitian Park, Bennet, Couture, dan Blanchard (2013) dimana jenis kelamin responden yang paling banyak laki-laki $79,3 \%$ dan . $71,4 \%$ pasien Skizofrenia di Amerika yaitu laki-laki.

National Institute of Mental Health (2008) dalam Shives (2012) menjelaskan Skizofrenia biasanya muncul pada laki-laki pada saat remaja akhir di usia 20 tahun atau dewasa awal atau pada usia 30 tahun. Angka kejadian relaps karena faktor ketidakpatuhan pengobatan terjadi pada laki-laki sebesar 53\% (Dewi \& Machira, 2009). Hal ini tidak sesuia dengan penelitian Andayani (2012) dimana lebih sebagian pasien Skizofrenia berpendidikan SMA 54,3\%. Penelitian ini juga tidak sejalan dengan penelitian Lv, Wolf, dan Wang (2013) 
bahwa pendidikan pasien Skizofrenia di China yang tamat SMA lebih sebagian $(65 \%)$.

Pendidikan merupakan sumber koping yang dapat menurunkan risiko meningkatnya stres yang berhubungan dengan gangguan jiwa atau dapat meningkatkan pemulihan (Stuart, 2013). Hal ini sesuai dengan penelitin pasien Skizofrenia yang belum menikah dominan yaitu $78,3 \%$. Penelitian ini didukung Mashiach-Eizenberg, et al. (2013) bahwa $78,2 \%$ pasien Skizofrenia di Amerika Serikat belum menikah. Pernikahan merupakan salah satu wujud kemampuan membina hubungan interpersonal serta menggambarkan bahwa pasien Skizofre-nia membutuhkan dukungan sosial dalam me-wujudkan kehidupan yang berarti (Üçok, et al., 2013).

Menurut Kasiati (2016: 85 \& 91) personal hygiene atau kebersihan diri adalah upaya seseorang dalam memelihara kebersihan dan kesehatan untuk memperoleh kesejahteraan fisik dan psikologis. Bila pemenuhan kebersihan diri klien tidak terpenuhi akan menimbulkan masalah, seperti gangguan fisik yaitu mucosa mulut, integritas kulit, dan lainlain, juga mengalami gangguan psikologis. Selain itu, Menurut Nurhalimah (2016: 221) tanda dan gejala defisit perawatan diri kepada pasien halusinasi dapat ditemukan melalui observasi salah satunya adalah Gangguan kebersihan diri, ditandai dengan rambut kotor, gigi kotor, kulit berdaki dan bau, kuku panjang dan kotor.

Hasil observasi yang telah dilakukan peneliti di lapangan sebanyak 2 kali terhadap pemenuhan kebersihan diri pada pasien skizofrenia dengan halusinasi, didapatkan lebih dari sebahagian pasien tampak bersih dalam kebersihan dirinya. Pasien terlihat dengan kondisi rambut bersih, gigi bersih, kulit bersih, badan wangi, kuku bersih dan pendek. Dan pasien juga mampu melakukannya sendiri tanpa dibantu oleh orang lain, dan tidak ada masalah yang muncul seperti gangguan fisik pada pasien skizofrenia dengan halusinasi di Wilayah Kerja Puskesmas Tanjung Paku Kota Solok.

Hasil penelitian ini sama dengan hasil penelitian Maryatun (2015) tentng peningkatan kemandirian perawatan diri pasien skizofrenia melalui rehabilitasi terapi gerak, bahwa separoh $(50 \%)$ dari seluruh responden yang mempunyai kemandirian perawatan diri yang baik telah melakukan terapi gerak dengan kombinasi gerakan perawatan diri.

Hasil penelitian ini juga sama dengan hasil penelitian Siahaan (2018) pada pasien skizofrenia di Poli Rumah Sakit Jiwa Prof. Dr M Ildrem Medan, bahwa dari 98 orang (100\%) responden memiliki persepsi perawatan diri dengan kategori baik. Hasil analisa data penelitian untuk perawatan diri (mandi) yang baik yaitu 98 responden (100\%). Mandi yang baik adalah seseorang yang mampu melakukan dan menyelesaikan aktivitas kehidupan seharihari secara mandiri, seperti adanya keinginan untuk mandi secara teratur, menyiapkan peralatan untuk mandi, menggunakan peralatan mandi seperti sabun, shampo dan gayung, mampu menggosok seluruh bagian badan saat mandi, mampu mengeringkan tubuh setelah mandi dengan menggunakan handuk, menggosok gigi pada saat setelah sarapan dan sebelum tidur.

Hasil penelitian ini berbeda dengan hasil penelitian Jalil (2015) tentang faktor yang mempengaruhi penurunan kemampuan pasien skizofrenia dalam melakukan perawatan di RSJ, menunjukkan bahwa adanya hubungan antara halusinasi dengan penurunan kemampuan perawatan diri dengan signifikan 0,006. Dan hasil analisis tabel silang menunjukkan $\quad 79,8 \%$ klien yang mengungkapkan pengalaman halusinasi juga menunjukkan penurunan kemampuan perawatan diri.

Hasil penelitian Madalise (2015) tentang pengaruh pendidikan kesehatan pada pasien gangguan jiwa (defisit perawatan diri) terhadap pelaksanaan ADL (activity of dayli living) kebersihan gigi dan mulut di RSJ Prof.Dr.V.L Ratumbuysang Ruang Katrili, bahwa pelaksanaan ADL responden sesudah diberikan pendidikan kesehatan tentang cara menggosok gigi yang baik dan benar menunjukkan bahwa pelaksanaan ADL mengalami peningkatan pelaksanaan ADL baik.

Berdasarkan hasil penelitian Sutinah (2017) tentang Terapi Aktivitas Kelompok (TAK) Stimulasi persepsi berpengaruh terhadap perawatan kebersihan diri klien skizofrenia dapat dilihat bahwa klien skizofrenia yang mengalami defisit perawatan diri sebelum dilakukan terapi aktivitas kelompok stimulasi persepsi kurang mampu melakukan perawatan 
kebersihan diri dengan nilai rata-rata adalah 8,05 .

Menurut Nurhalimah (2016) tanda dan gejala defisit perawatan diri kepada pasien halusinasi dapat ditemukan melalui observasi salah satunyaadalah ketidakmampuan berhias/berdandan, ditandai dengan rambut acak-acakkan, pakaian kotor dan tidak rapi, pakaian tidak sesuai, pada pasien laki-laki tidak bercukur, pada pasien wanita tidak berdandan.Dari hasil observasi yang telah dilakukan peneliti di lapangan sebanyak 2 kali terhadap perawatan diri dalam berhias diri pada pasien skizofrenia dengan halusinasidi Wilayah Kerja Puskesmas Tanjung Paku Kota Solok, didapatkan sebahagian besar pasien mampu dalam berhias diri. Pasien tampak rambut rapi, pakaian bersih dan rapi, pakaian sesuai, pada pasien laki-laki bercukur/pada pasien perempuan tampak berdandan, memakai sepatu/sendal, mengkancingkan baju atau celana.

Hasil penelitian ini sama dengan hasil penelitian Siahaan (2018) pada pasien skizofrenia di Poli Rumah Sakit Jiwa Prof. Dr M Ildrem Medan, yang menunjukkan bahwa dari 98 orang $(100 \%)$ responden memiliki persepsi perawatan diri dengan kategori baik. Hasil analisa data penelitian untuk perawatan diri (berpakaian) yang baik yaitu 98 responden (100\%). Berpakaian yang baik adalah seseorang yang mampu melakukan dan menyelesaikan aktivitas kehidupan sehari-hari secara mandiri, seperti adanya keinginan untuk mengganti pakaian yang kotor setelah mandi, menggunakan pakaian yang lengkap, mampu menjaga kebersihan pakaian, menempatkan pakaian yang kotor ditempatnya, mampu membedakan pakaian yang kotor dan bersih, menggunting kuku jika panjang.

Berdasarkan hasil penelitian Emilyani (2014) tentang Pengaruh Terapi Kelompok Suportif Terhadap Kemandirian Pasien Skizofrenia Yang Mengalami Defisit Perawatan Diri, bahwa kemandirian pasien skizofrenia setelah dilakukan terapi suportif untuk melakukan perawatan diri: Berdandan/berhias, sebagian besar 55,5\% responden mampu melakukan dengan bantuan. Hasil penelitian Sasmita (2012) tentang Pengaruh Metode Token Economy terhadap aktivitas perawatan diri pada pasien defisit perawatan diri di ruang Melati Rumah Sakit Prof.HB.Sa'anin Padang, bahwa terdapat perbedaan bermakna antara aktifitas berhias diri sebelum diberikan metode token economy dengan sesudah diberikan metode token economy.

Menurut Nurhalimah (2016) tanda dan gejala defisit perawatan diri kepada pasien halusinasi dapat ditemukan melalui observasi salah satunyaadalah ketidakmampuan makan secara mandiri, ditandai dengan ketidakmampuan mengambil makan sendiri, makan berceceran, dan makan tidak pada tempatnya. Hasil observasi yang telah dilakukan peneliti di lapangan sebanyak 2 kali terhadap perawatan diri dalam makan pada pasien skizofrenia dengan halusinasi di Wilayah Kerja Puskesmas Tanjung Paku Kota Solok, didapatkan hampir keseluruhan pasien mampu dalam makan. Pasien tampak mampu menggunakan peralatan makan, mencuci tangan sebelum dan sesudah makan, mampu mengambil makanan sendiri, makan pada tempatnya/tertib, tampak mengunyah makanan dengan baik, tampak mulut bersih dari sisa-sisa makanan di sekitar mulut.

Hasil penelitian ini sama dengan hasil penelitian Siahaan (2018) pada pasien skizofrenia di Poli Rumah Sakit Jiwa Prof. Dr M Ildrem Medan, didapat keseluruhan responden memiliki persepsi tentang perawatan diri (makan) yang baik yaitu 98 responden $(100 \%)$. Makan yang baik adalah kemampuan untuk menunjukkan aktivitas makan seperti mampu untuk mempersiapkan makanan, menyiapkan alat untuk makan, mampu menggunakan alat tambahan (sendok makan), cuci tangan sebelum makan dan sesudah makan, mengambil cangkir atau gelas, mendapat makanan, mampu untuk mengunyah makanan, mampu memanipulasi makanan dalam mulut, mampu mengambil makanan dari wadah lalu memasukkannya ke dalam mulut, mampu mencerna makanan menurut cara diterima masyarakat, serta mencerna makanan cukup aman.

Hasil penelitian Emilyani (2014) tentang pengaruh terapi kelompok suportif terhadap kemandirian pasien skizofrenia yang mengalami defisit perawatan diri, bahwa kemandirian pasien skizofrenia setelah dilakukan terapi suportif untuk melakukan perawatan diri: makan dan minum, sebagian besar 88,8\% mampu melakuka tanpa bantuan. Hasil penelitian Rini tentang Activity Of Daily Living (ADL) untuk meningkatkan kemampuan rawat diri pada pasien skizofrenia 
tipe paranoid bahwa terapi perilaku yaitu Activity of Daily Living (ADL) dapat meningkatkan keterampilan atau kemampuan merawat diri pada subjek dengan gangguan skizofrenia.

Menurut Nurhalimah (2016: 221) tanda dan gejala defisit perawatan diri pada pasien halusinasi dapat ditemukan melalui observasi salah satunya adalah ketidakmampuan defekasi/berkemih secara mandiri, ditandai dengan defekasi/berkemih tidak pada tempatnya, tidak membersihkan diri dengan baik setelah defekasi/berkemih. Hasil observasi yang telah dilakukan peneliti di lapangan sebanyak 2 kali terhadap perawatan diri dalam BAB/BAK pada pasien skizofrenia dengan halusinasi di Wilayah Kerja Puskesmas Tanjung Paku Kota Solok,didapatkan hampir keseluruhan pasien tampak bersih setelah BAB/BAK. Pasien tampak tangannya bersih dan tidak ada sisa-sisa feses setelah $\mathrm{BAB} / \mathrm{BAK}$, tampak tempat $\mathrm{BAB} / \mathrm{BAK}$ (WC) tidak kotor/bersih, tampak pakaiannya terpasang rapi dan tidak bau setelah $\mathrm{BAB} / \mathrm{BAK}$.

Hasil penelitian ini sama dengan hasil penelitiaan Siahaan (2018) tentang persepsi pasien skizofrenia tentang perawatan diri di RSJ Prof dr M Ildrem Medan, bahwa analisa data penelitian untuk perawatan diri (toileting) pada pasien skizofrenia, didapat keseluruhan responden, memiliki persepsi tentang perawatan diri (toilleting) yang baik yaitu 98 respoden (100\%). Eliminasi atau toileting yang baik adalah kemampuan untuk melakukan atau menyelesaikan aktivitas toileting sendiri, seperti mampu dalam mendapatkan jamban atau kamar kecil, mampu duduk atau bangkit dari jamban, mampu untuk memanipulasi pakaian untuk toileting, mampu membersihkan diri setelah BAB/BAK dengan tepat, dan mampu untuk menyiram toilet.

Hasil penelitian ini berbeda dengan hasil penelitan Pinedendi (2016) tentang pengaruh penerapan asuhan keperawatan defisit perawatan diri terhadap kemandirian personal hygiene pada pasien di RSJ.Prof.V.L.Ratumbuysang Manado, bahwa tingkat kemandirian personal hygiene pada pasien sesudah diberikan intervensi menunjukkan paling banyak berada pada kategori ketergantungan sedang $(48,1 \%)$.

Hasil penelitian yang dilakukan oleh Hastuti
(2018) tentang pengaruh pelaksanaan jadwal harian perawatan diri terhadap tingkat kemandirian merawat diri pada pasien skizofrenia di RSJD DR.RM Sodjawardi di Provinsi Jawa Tengah, bahwa sebagian besar pasien skizofrenia sebelum jadwal perawatan diri, tingkat kemandirian perawatan dirinya masih kurang. Hasil penelitian Trihardani (2009) tentang tingkat pemenuhan aktivitas sehari-hari pasien skizofrenia di rlingkup kerja Puskesmas Gombong II, yang terdiri dari aktivitas mandi/kebersihan diri, berpakaian/berdandan, makan/minum, dan eliminasi $\mathrm{BAB} / \mathrm{BAK}$ secara umum penderita skizofrenia diketahui bahwa persentase tertinggi $38 \%$, penderita skizofrenia masuk kategori ketergantungan ringan. Berdasarkan hasil penelitian Susanti (2010), tentang Defisit Perwatan Diri Pada Klien Skizofrenia Aplikasi Teori Keperawata Orem, bahwa manifestasi dari defisit perawatan diri terkait dengan ketidakmampuan untuk melakukan satu dari kebutuhan dasar dari ADL seperti makan, personal hygiene, berpakaian, toileting, tidur, interaksi sosial, atau keamanan.

Hasil penelitian dari Wardaningsih (2010) tentang gambaran strategi koping keluarga dalam merawat pasien skizofrenia di wilayah Kecamatan Kasihan Bantul bahwa faktorfaktor yang dapat mempengaruhi strategi koping keluarga dalam merawat penderita gangguan jiwa yaitu terdiri dari faktor keuangan (status sosial ekonomi), faktor keyakinan (agama), faktor dukungan sosial, faktor pengetahuan keluarga, dan faktor polapola komunikasi.

\section{SIMPULAN}

Hasil penelitian disimpulkan bahwa lebih dari sebahagian $(62,5 \%)$ responden tampak bersih dalam kebersihan dirinya, sebahagian besar (75\%) responden tampak mampu dalam berhias diri, hampir keseluruhan (96,9\%) responden tampak mampu dalam makan, hampir keseluruhan $(96,9 \%)$ responden tampak bersih setelah $\mathrm{BAB}$ dan $\mathrm{BAK}$.

\section{DAFTAR PUSTAKA}

Andayani, S. (2012). Hubungan Karakteristisk Klien Skizofrenia Dengan Tingkat Kemampuan Perawatan Diri Di Ruang Rawat Inap Psikiatri Wanita Rumah Sakit Marzoeki Mahdi Bogor. Universitas Indonesia, Depok.

Asmadi. (2008). Konsep Dasar Keperawatan. 
Jakarta: EGC.

Balitbangkes Kemenkes RI. (2013). Riskesdas 2013.

Balitbangkes Kemenkes RI. (2018). Riskesdas 2018.

Baradero, D. \& M. (2010). Asuhan Keperawatan Kesehatan Mental Psikiatri. Jakarta: EGC.

Dewi, R., \& Machira, C.R. (2009). Riwayat Gangguan Jiwa pada Keluarga dengan Kekambuhan Pasien Skizofrenia di RSUP dr Sarjito Yogyakarta. Berita Kedokteran Masyarakat, 25 (4), 176179. $10.22146 / \mathrm{bkm} .3551$

https://doi.org/

Emilyani, D. (2014). Pengaruh Terapi Kelompok Suportif Terhadap Kemandirian Pasien Skizofrenia Yang Mengalami Defisit Perawatan Diri Di Rumah Sakit Jiwa Propinsi NTB. Jurnal Medika Bio Sains, 2(2), 171-180.

Hamid \& Ibrahim. (2017). Pakar Teori Keperawatan dan Karya Mereka edisi 8, volume 1. Jakarta: Elsevier.

Hastuti \& Rohmat. (2018). Pengaruh Pelaksanaan Jadwal Harian Perawatan Diri Terhadap Tingkat Kemandirian Merawat Diri Pada Pasien Skizofrenia Di RSJD DR. RM SOEDJARWADI Provinsi Jawa Tengah. GASTER, $X V I(2)$

Jalil, A. (2015). Faktor Yang Mempengaruh Penurunan Kemampuan Pasien Skizofrenia Dalam Melakukan Perawatan Di Rumah Sakit Jiwa. Jurnal Keperawatan Jiwa, 3(2), 154-161.

Kasiati \& Rosmalawati. (2016). Kebutuhan Dasat Manusia I. Jakarta Selatan: Kemenkes RI.

Keliat, Budi Anna, D. (2011). Keperawatan Kesehatan Jiwa Komunitas CMHN (Basic Course). Jakarta: EGC.

Kusumawati \& Hartono. (2010). Buku Ajar Keperawatan Jiwa. Jakarta: Salemba Medika.

Lisa \& Sutrisna. (2013). $\quad N_{C}{ }^{\prime}{ }^{\prime}$
Psikotropika, Dan Gangguan Jiwa Tinjauan Kesehatan dan Hukum. Yogyakarta: Nuha Medika.

Lv, Y., Wolf, A., \& Wang, X. (2013). Experience stigma and self stigma in Chinese patients with Schizophrenia. General Hospital Psychiatry, 35 (1), 8388. doi: 10.1016/ j.genhosppsych.2012.07.007.

Madalise, Bidjuni, \& W. (2015). Pengaruh Pemberian Pendidikan Kesehatan Pada Pasien Gangguan Jiwa (Defisit Perawatan Diri)Terhadap Pelaksanaan ADL (Activity Of Dayli Living) Kebersihan Gigi dan Mulut Di RSJ Prof.Dr. V. L RATUMBUYSANG RUANG KATRILI. Ejournal Keperawatan (e-Kp), 3(2).

Maryatun, S. (2013). Peningkatan Kemandirian Perawatan Diri Pasien Skizofrenia Melalui Rehabilitasi Terapi Gerak. Jurnal Keperawatan Sriwijaya, 2(2), 108-114.

Mashiach-Eizenberg, M., Hasson-Ohayon, I., Yanos, P.T., Lysaker, P.H., \& Roe, D. (2013). Internalized Stigma quality of life among persons with severe mental illness: The mediating roles of self esteem and hope. Psychiatric Research, 208 (1), 15-20. doi: 10.1016/j.psychres.2013.03.013.

Muhith, A. (2015). Pendidikan Keperawatan Jiwa Teori dan Aplikasi. Yogyakarta: Andi.

Nasir \& Muhith. (2011). Dasar-Dasar Keperawatan Jiwa Pengantar dan Teori. Jakarta: Salemba Medika.

Notoatmodjo, S. (2010). Metodologi Penelitian Kesehatan. Jakarta: Rineka Cipta.

Nurhalimah. (2016). Modul Bahan Ajar Cetak Keperawatan Jiwa. Jakarta Selatan: Kemenkes RI.

O’Brien, Kennedy, \& B. (2014). Keperawatan Kesehatan Jiwa Psikiatrik Teori \& Praktik. Jakarta: Buku Kedokteran EGC.

Park, S.G, Bennett, M.E., Couture, S.M., \& Blanchard, J.J. (2013). Internalized stigma in schizophrenia: Relations with 
dysfunctional attitudes, symptoms and quality of life. Psychiatry Res, 205 (12), 43-47. doi: 10.1016/j.psychres.2012.08.040.

Pinedendi, N., Rottie, J. V., Wowiling, F., Studi, P., Keperawatan, I., Kedokteran, F., \& Ratulangi, U. S. (2016). Pengaruh Penerapan Asuhan Keperawatan Perawatan Diri Terhadap Kem Personal Hygiene Pada Pasien di RSJ.Prof.V.L.Ratumbuysang Manado. $E$ Journal Keperawatan (e-Kp), 4(2).

Potter \& Perry. (2010). Fundamental Keperawatan buku 1, edisi 7. Jakarta: Salemba Medika.

Prabowo, E. (2014a). Buku Ajar Keperawatan Jiwa. Yogyakarta: Nuha Medika.

Prabowo, E. (2014b). Konsep \& Aplikasi Asuhan Keperawatan Jiwa. Yogyakarta: Nuha Medika.

Purba, J. M. \& dkk. (2010). Asuhan Keperawatan Pada Klien dengan Masalah Psikososial dan Gangguan Jiwa. Medan: USU Press.

Rini, A. S. (2016). Activity Of Daily Living (ADL) Untuk Meningkatkan Kemampuan Rawat Diri. Dinamika Penelitian, 16(2).

Riyadi \& Purwanto. (2009). Asuhan Keperawata Jiwa. Yogyakarta: Graha Ilmu.

Sasmita, H., \& Mahdairta, R. (2012). Pengaruh Metode Token Economy Terhadap Aktifitas Perawatan Diri pada Pasien Defisit Perawatan Diri. Ners Jurnal Keperawatan, 8(1), 23-30.

Sharaf, A.Y., Ossman, L.H., \& Lachine, O.A. (2012). A cross-sectional study of the relationships between illness insight, inter-nalized stigma, and suicide risk in individuals with Schizophrenia. International Journal of Nursing Studies, 49 (12), 1512-1520. doi: 10.1016/j.ijnurstu.2012.08.006

Siahaan, E. S. (2018). Persepsi Pasien Skizofrenia Tentang Perawatan Diri di Rumah Sakit Jiwa Prof dr M Ildrem
Medan. Universitas Sumatera Utara.

Sibitz, I., Amering, M., Unger, A., Seyringer M.E., Bachmann, A., Schrank. B., Benesch, T., Schulze, B., \& Woppmann. A. (2011). The impact of social network, stigma and empowerment on the quality of life in patients with schizophrenia. European Psychiatry, 26, 28-33. doi: 10.1016/j.eurpsy. 2010.08.010.

Shives, L.R. (2012). Basic concepts of psychiatric-mental health nursins reth Ed.). Florida: Wolters Lippincott Williams \& Wilkins.

Staring, A.B.P, Van der Gaag, M., Van den Berge, M., Duivenvoorden, H.J, \& Mulder, C.L. (2009). Stigma moderates the associations of insight depressed mood, low self-esteem low quality of life in patients with schizophrenia. Schizophrenia Research, 115 (2-3), 363-369. doi: 10.1016/j.schres. 2009.06.015

Stuart, G.W. (2013). Principles and Practice Psychiatric Nursing (10th Ed.). St. Louis: Elsevier/Mosby.

Stuart, G. W. (2016). Prinsip dan Praktik Keperawatan Kesehatan Jiwa Stuart. Singapura: Elsevier.

Susanti, H. (2010). Defisit Perawatan Diri Pada Klin Skizofrenia: Aplikasi Teori Keperawatan Orem. Jurnal Keperawatan Indonesia, 13(2), 87-97.

Sutejo. (2017). Keperawatan Kesehatan Jiwa Prinsip dan Praktik Asuhan Keperawatan Jiwa. Yogyakarta: Pusktaka Bru Press.

Sutinah \& Mardiansyah. (2017). Terapi aktivitas kelompok(TAK) stimulasi persepsi berpengaruh terhadap perawatan kebersihan diri klien skizofrenia. Riset Informasi Kesehatan, 6(2).

Tarwoto \& Wartonah. (2011). Kebutuhan Dasar Manusia Dan Proses Keperawatan edisi 4. Jakarta Selatan: Salemba Medika.

Trihardani, L. (2009). Tingkat Pemenuhan 
Aktivitas Sehari-Hari Pasien Skizofrenia di Rlingkup Kerja Puskesmas Gombong II. Jurnal Ilmiah Kesehatan Keperawatan, 5(1), 43-55.

Üçok, A., Karadayi, G., Emiroğlu, B., \& Sartorius, N. (2013). Anticipated discrimination is related to symptom severity, functionality and quality of life schizofrenia. Psychiatry Research, 209 (3), 333-339. doi: 10.1016/ j.psychres.2013.02.022.

Videbeck, S. (2008). Buku Ajar Keperawatan Jiwa. Jakarta: EGC.

Videbeck, S.L. (2011). Psychiatric mental health nursing (5th Ed.). Philadelphia: Lippincott Williams \& Walkins.

Wardaningsih, S., Rochmawati, E., \& Sutarjo, P. (2010). Gambaran Strategi Koping Keluarga dalam Merawat Pasien Skizofrenia di Wilayah Kecamatan Kasihan Bantul. Mutiara Medika, 10(1), 55-61.

Yosep, I. (2009). Keperawatan Jiwa. Bandung: Refika Aditama.

Yudhantara \& Istiqomah. (2018). Si Skizofrenia Untuk Mahe Kedokteran. Jakarta: UB Press.

Yusuf, F. \& N. (2015). Buku Ajar Keperawatan Kesehatan Jiwa. Jakarta Selatan: Salemba Medika. 
Jurnal Keperawatan Jiwa Volume 8 No 1 Hal 9 - 20, Februari 2020

FIKKes Universitas Muhammadiyah Semarang bekerjasama dengan PPNI Jawa Tengah 